\title{
Investigation of dependences of metal sheet variable blank holding force
}

\author{
R. Bortkevičius*, R. Dundulis**, R. Karpavičius*** \\ *Kaunas University of Technology, Kestučio 27,44312 Kaunas, Lithuania, E-mail: r.bortkevicius@kaispauk.lt \\ **Kaunas University of Technology, Kęstučio 27,44312 Kaunas, Lithuania,E-mail: romdun@ktu.lt \\ ***Kaunas University of Technology, Kęstučio 27, 44312 Kaunas, Lithuania, E-mail: rimkarp@stud.ktu.lt
}

crossref $\mathrm{http}: / / \mathrm{dx}$.doi.org/10.5755/j01.mech.17.3.496

\section{Introduction}

The purpose of this investigation is to characterize and latter make a full development of variable metal sheet blank holding force (VBHF). Permanent blank holding force has been used so far (Fig. 1). The present paper is a continuation of authors' papers. Until present day optimal dependence of minimal blank holding force on punch travel in order to avoid the wrinkles has not been identified, even in theory [1-3]. All theoretical formulations of blank holding force (BHF) describe only the maximum of $\mathrm{BHF}$, which does not describe nonlinearity in metal forming operation. From literature [4] we know the holding maximum pressure to the sheet should be around 1 $3 \mathrm{MPa}$. Several analytical equations have been invented or derived in order to characterize BHF. For example scientists $[1,2,5]$ describes the following equation for needed $\mathrm{BHF}$

$$
F_{B H F}=b F_{D R} \sin \left(\frac{\pi}{2} \frac{h}{h_{\max }}\right)
$$

The given equation describes $\mathrm{BHF}$ as the dependence on punch traveling distance $h, \mathrm{~mm}$. The same authors change travel $h$ into time $t, \mathrm{~s}$ and get BHF as the dependence on punch traveling time.

$$
F_{B H F}=b F_{D R} \sin \left(\frac{\pi}{2} \frac{t}{t_{\max }}\right)
$$

where $b$ is empiric coefficient; $F_{D R}$ is drawing force, $h_{\max }$ and $t_{\max }$ are maximal piece depth and suitable process duration [1]. Another two authors [4, 6] give the same equation for constant blank holding force (CBHF), $\mathrm{N}$

$$
F_{B H F}=\frac{\pi}{4}\left(D^{2}-\left(d+2 g r^{2}\right)\right) p
$$

Or simplified

$$
F_{B H F}=\frac{\pi}{4}\left(D^{2}-d^{2}\right) p
$$

where $D$ is outer diameter of the workpiece, $d$ is diameter of formed part, $r$ is corner radius, $p$ is pressure. The comparisons of VBHF to CBHF will be provided. By our opinion $F_{B H F}$ falls below zero line or the equation gives linear dependency of BHF vs. time, and that is not acceptable with the results provided in literature [7], where relative VBHF shapes are investigated. One of the reasons

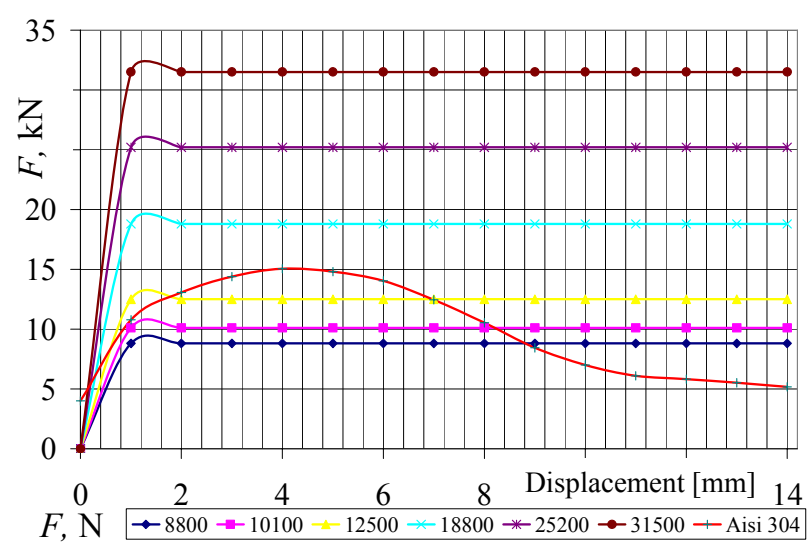

Fig. 1 Permanent blank holding force model

why BHF should be controlled is described in the articles $[2,5,8]$, were clearly exists a description. This paper formulates nonlinear dependency of BHF versus time or punch traveling distance. Pulsating blank holding force [9] does fall into our view and stays behind the scope of our investigations though its shape can be also described as nonlinear variable blank holding force. The experimental results will present data extracted from finite element analysis (FEMA) and analytically formulated VBHF. Validation of the given results can be found in the paper [5]. Mathematical formulation [10] of variable blank holding force (latter VBHF) presented here represent nonlinear relation of holder force versus punch displacement (or time).

$$
F_{v b h f}=q+b\left[\frac{L t_{0}^{2} T_{\text {tension }}}{W}\right] \sin \alpha
$$

where $q, b$ are empirical coefficients, depending on chosen material, $L$ is the length of forming material [11], $t_{0}$ is thickness of the sheet, $T_{\text {tension }}$ is tension of the material to the principle direction, $W$ is die opening clearance, $\alpha$ is angle of change of vertical part of material, it represents the shape function of the blank holding curve. The most important factor in the equation is its coefficients. We determined these coefficients by choosing to examine the punch force needed to withdraw the correct stamped part. The examination of this force for different material mechanical properties is given in the article [12]. The results expected here we hope will allow to employ given equation into industrial manufacturing of metal sheet part. Since we investigated 3 most common material models, we believe that given equation meets the highest standards for requirement of choosing blank holding force. Our analysis is based on numerical formulation and calculation. Since 
we equalize mechanical properties given from Finite element modeling analysis (FEMA) with those from real researches in nature $[2,3,13]$, we state, that results from FEMA are correct and correlate with real researches. Therefore FEMA analysis results can be treated as reliable. Development of VBHF theory consists of a plenty of experiments made to determine metal sheet stiffness, thickness, spring back angle and so forth. Also big attention must be paid to gain correct stress strain properties of the investigated materials. We build up our model reliance on strength proportionality constant or simply strength coefficient $K[12,13]$ and coefficient $\mathrm{n}$ from stress strain curves in order to get a curve slope (angle). The place, where the change of phase should begin or end up is determined from metal sheets stiffness curves. The first and the last points of VBHF are determined empirically. The calculated strength coefficient $K[12,13]$ and investigated materials are given in the Table 1 [6]. Another important factor in equation is $f[\sin \alpha]$ which describes shape function of the deformed part. This shape function is very important, because it shows the separation of drawing part and bending part and describes when it begins and ends.

Table 1

Strength coefficients

\begin{tabular}{|l|l|l|}
\hline Material & Coefficient $K$ & Coefficient $n$ \\
\hline AW 6082-T6 & 590 & 0.3 \\
\hline L63 & 1600 & 0.6 \\
\hline AISI 304 & 1400 & 0.45 \\
\hline
\end{tabular}

Initial blank holding force was calculated with Eqs. (6), (7) . This equation gives the first standpoint of initial BHF. Since this equation gives needed force $F_{L 63}$ to withdraw material to a needed shape, BHF must be higher.

$$
\begin{aligned}
& F_{b h f L 63}=\frac{L t_{0}^{2}\left(\sigma_{u t}\right)}{W} \\
& F_{b h f L 63}>\frac{L t_{0}^{2}\left(\sigma_{u t}\right)}{W}
\end{aligned}
$$

where $F_{b h f L 63}$ is BHF for investigated materials, $L$ is the length of supporting place, $t_{0}$ is initial thickness, $\sigma_{u t}$ is ultimate tensile strength [14], $W$ is the gap between the punch and matrix. For the investigated materials initial

$$
\mathrm{BHF} \quad \text { is } \quad F_{a w 6082} \cong 10350 \mathrm{~N}, \quad F_{L 63} \cong 13216.5 \mathrm{~N} \text {, }
$$$$
F_{\text {AISI } 304} \cong 30015 \mathrm{~N} \text {. }
$$

\section{Methods of investigation}

Testing was conducting using two common models: analytical equations and Finite element analysis (FEMA) described in the literature [7, 5, 12].

The overall description of the investigated model including boundary conditions, mechanical properties of investigated materials can be found in the [12]. Schematically the model is shown in Fig. 2. Here computational model is presented with three punch displacement steps. During deformation of metal sheet deformation was measured, since we need the highest value of plastic strains. Measurements were taken from the top surfaces of the de-

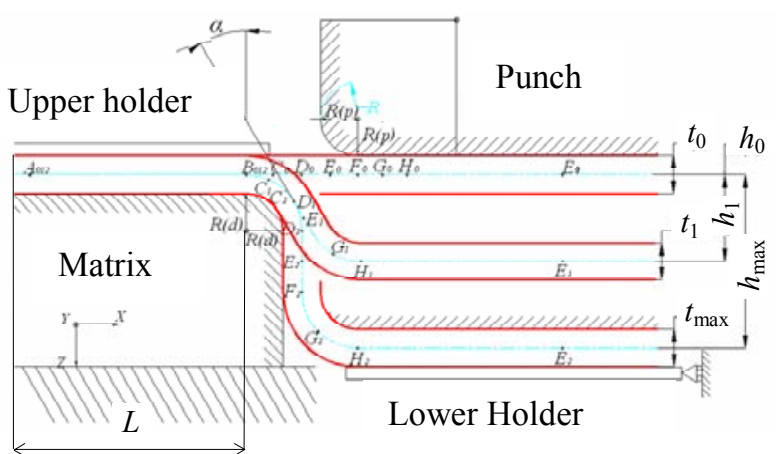

Fig. 2 Kinematics of model in forming operation and measuring angle

formed part. Since our model was divided into many of equal rectangulars, after the deformation these rectangulars were changed into rhomboids. The dimensions of initial grid were 0.5 and $0.1 \mathrm{~mm}$ space between grids [9, 15]. If the deformation runs on general plane stress sheet conditions are measured by coefficient $\beta$ [13], which is defined as

$$
\beta=\frac{\varepsilon_{2}}{\varepsilon_{1}}=\frac{\ln \left(d_{2} / d_{0}\right)}{\ln \left(d_{1} / d_{0}\right)}
$$

where $d_{0}$ is the undeformed state with circle and square grids marked on an element of the sheet, $d_{1}$ is the deformed state with the grid squares deformed to rhomboid of major diameter $d_{1}, d_{2}$ is the deformed state with the grid squares deformed to rhomboids of minor diameter $d_{2}[3$, 13].

\section{Geometrical variable}

Since we investigate geometrical variables in metal sheet forming, serious consideration must be taken into account while measuring punch displacement in accordance to the angle change of vertical part place. By the investigation described here - angle to displacement ratio is almost linear only until the 10 th step, i.e. $10 \mathrm{~mm}$ downward, latter ratio $R$ changes keeping linear correlation to angle and until punch reaches its maximum downward point $(14 \mathrm{~mm})$. Correlation of the described angle versus displacement can be seen in Fig. 3. In the same figure there are clearly divided linear and nonlinear phases of the change of angle versus displacement. It is clear that linear to nonlinear phase of ratio change starts at $10 \mathrm{~mm}$ of the punch displacement. On another hand it can happen than bending of the metal sheet plate is finished and its deep drawing begins. So we must emphasize that we are developing VBHF for the combination of bending and deep drawing operations of metal sheet forming. This can also be proven by investigating material [11] stiffness curve of the same experimental model. In the Fig. 4 clearly can be seen that when material experiences a bending and when its phase changes from bending to deep drawing - the same is the punch displacement $10 \mathrm{~mm}$. the described figure is metal sheet stiffness curve for the chosen material stainless steel grade AISI 304. The mentioned stiffness curves were gained using constant metal sheet holding force. The familiar metal sheet stiffness curve can bee seen 


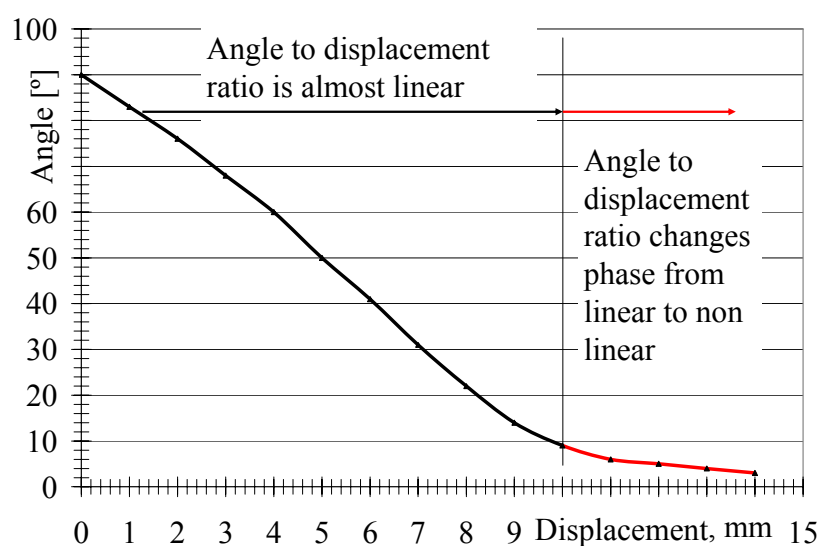

Fig. 3 Correlation of metal sheet angle versus punch displacement

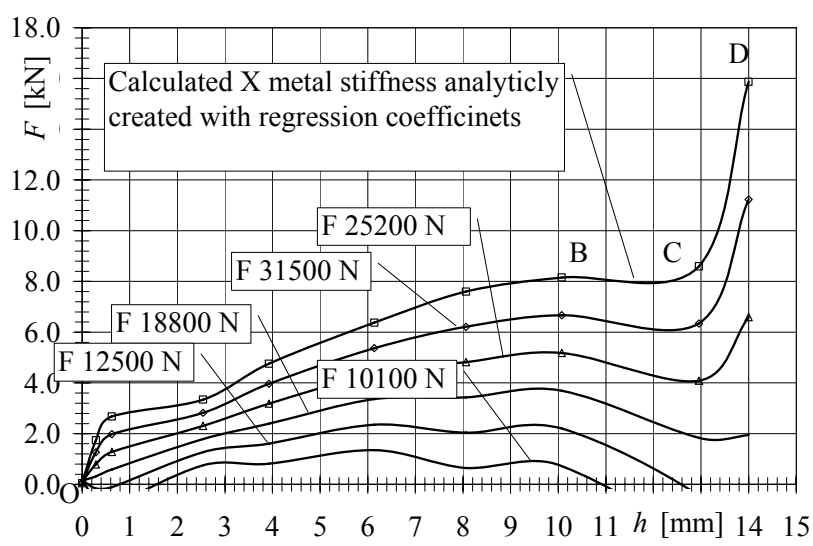

Fig. 4 Calculated metal sheet stiffness curve for forming part: Material stainless steel AISI 304

in [12]. The previous figure brings us proof that the change of angle has non linear dependence on displacement, and it can be considered straightforward in the investigation of VBHF. Serious consideration must be taken in the interpretation of aspect ratio $R$

$$
R=\frac{\alpha}{h}
$$

Latter we develop an equation of VBHF for the chosen analysis model. This equation has to be created from two parts. One part shall describe linear or bending processes (since we know that until $10 \mathrm{~mm}$ of punch displacement only bending deformations) occur and the second part of equation shall describe deep drawing processes (since we know that after $10 \mathrm{~mm}$ of punch displacement deep drawing deformations occur). Linear and non linear parts of bending and deep drawing are universal and they do not depend on material properties and fit to all kinds of metal sheet parts. The full development of the proposed variable blank holding force is defined below

$$
F_{v b h f}=q+b\left[\frac{L t_{0}^{2} T_{\text {tension }}}{W}\right] \sin \alpha
$$

Our model should be deformed according to equa-

tion

$$
\sigma_{1}=K \varepsilon^{n}
$$

$$
\begin{aligned}
& T_{\text {tension }}=\sigma t \\
& T_{\text {tension }}=\sigma_{1} t_{0} \exp (-\mu \theta) \\
& \mu=\mu_{D}+\left(\mu_{S}-\mu_{D}\right) \exp (-\dot{\varepsilon}) \\
& \dot{\varepsilon}=\frac{v}{h} \\
& F_{v b h f}=q+b \times \\
& \times\left[\frac{L t_{0}^{2} K \varepsilon^{n} t_{0} \exp \left(\left(-\left(\mu_{D}+\left(\mu_{S}-\mu_{D}\right) \exp (-\dot{\varepsilon})\right)\right) \theta\right)}{W}\right] \times \\
& \times f(\sin \alpha)
\end{aligned}
$$

where $q, b$ are empirical coefficients, depending on chosen material, $L$ is the length of forming material, $t_{0}=f(h)$ is thickness of the sheet as a function of displacement, $T_{\text {tension }}$ is ultimate tensile tension of the material, $W$ is die opening clearance, $\alpha$ is the angle of change of vertical part of material. $\sigma$ is tension properties of material, $\mu$ is friction coefficient, $\mu_{s}$ is static friction coefficient, $\mu_{d}$ is dynamic friction coefficient, $\dot{\varepsilon}$ is the speed of deformation. The graphical representation of Eq. (16) can be seen in the Fig. 6 andFig. 7 below. In the figures four curves for the investigated materials (AISI 304, L63, and AW6082-T6) can be seen. The mentioned curves represent VBHF versus punch displacement. In the beginning of deformation of metal sheet the blank holding force begins to acquire the value from zero until it reaches the highest possible value and suppresses the sheet. Later on VBH force acquires much lower values it follows thence that the stiffness of the curve also reduces its value accordingly.

Table 2

Angle versus punch displacement

\begin{tabular}{|c|c|c|c|}
\hline $\begin{array}{l}\text { Punch dis- } \\
\text { placement, mm }\end{array}$ & $\begin{array}{c}\text { Change of } \\
\text { angle, }^{\circ}\end{array}$ & $\begin{array}{c}\text { Punch dis- } \\
\text { placement, mm }\end{array}$ & $\begin{array}{c}\text { Change of } \\
\text { angle, }^{\circ}\end{array}$ \\
\hline 0 & 90 & 8 & 22 \\
\hline 1 & 83 & 9 & 14 \\
\hline 2 & 76 & 10 & 9 \\
\hline 3 & 68 & 11 & 6 \\
\hline 4 & 60 & 12 & 5 \\
\hline 5 & 50 & 13 & 4 \\
\hline 6 & 41 & 14 & 3 \\
\hline 7 & 31 & & \\
\hline
\end{tabular}

The angle of the sheet between the punch changes its vertical position while the punch moving downward by the values written in the Table 2. The main idea of VBHF is to reduce maximum material stiffness in order to avoid excessiveness of strength of material fatigue. The part, while being deformed, must always slide over the punch surface and must if possible avoid tension deformation.

\section{Investigation results}

According to Eq. (1) and (2) the calculated variable blank holding force is plotted in Fig. 5, where VBHF for investigated material AISI 304 can be seen. Needless to say that the mentioned VBHF does not fall 


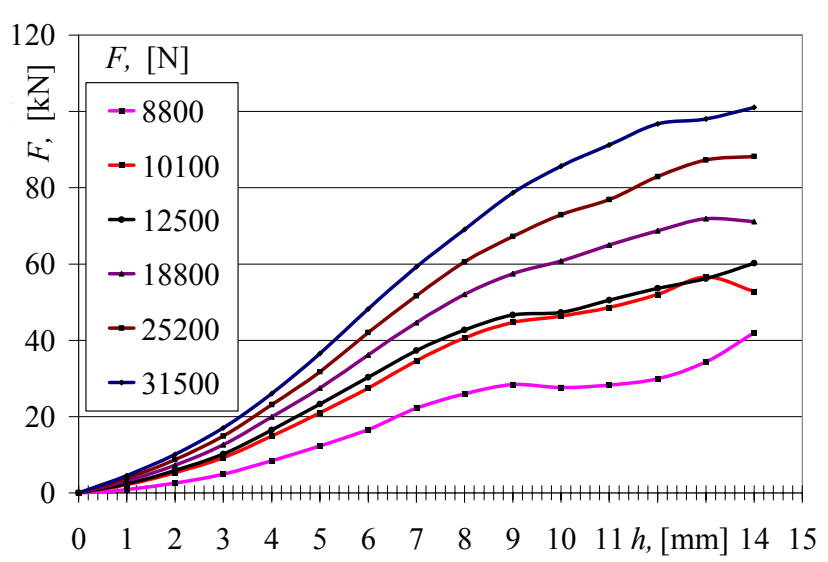

Fig. 5 VBHF for investigated material AISI 304

under the expected VBHF shape. Expected or wanted shape should be within the range of $31500 \mathrm{~N}$ and $8800 \mathrm{~N}$ with some tolerance of course. In the beginning the onset of the shape can be few times higher than the one which acts while the sheet is being deformed. In Fig. 5 VBHF shape at the beginning rises very high up to $100 \mathrm{t}-$ and that is not correct, because this value can seriously damage the forming sheet. Deformation of the metal sheet ends without any inclination of the curve in order to depress suppressing force - and that is also incorrect, because this value can influence significantly spring back angle and final shape of the part. Metal sheet stiffness (for investigated materials AISI 304, L63, AW6082-T6) calculated with VBHF (calculated with (16)) can be plotted in Fig. 6 and Fig. 7. There can be seen four curves for the investigated materials. The final plastic strain value does not depend on initial metal sheet place on the die, i.e. the metal sheet can be pushed in any direction and that



Fig. 6 Stiffness curve of a formed part from material AISI 304 (formed with VBHF)

does not have any influence on plastic strain state. Plastic strain begins besides bending radius though plastic strain originated at the one of the radii does not have any influence on plastic strains originated at the other bending radius while the part is being deformed. Plastic strain value of course grows while the part is being deformed and moves towards that direction in which is the place where stress grows. In the Fig. 8 below can be seen the relation of coefficient $b$ with to punch displacement for material AW 6082-T6. As coefficient $b$ changes (grows) its phase from value 0.1 to 0.5 the growth of curve steepness can be seen clearly in the place where the part is being bend (from

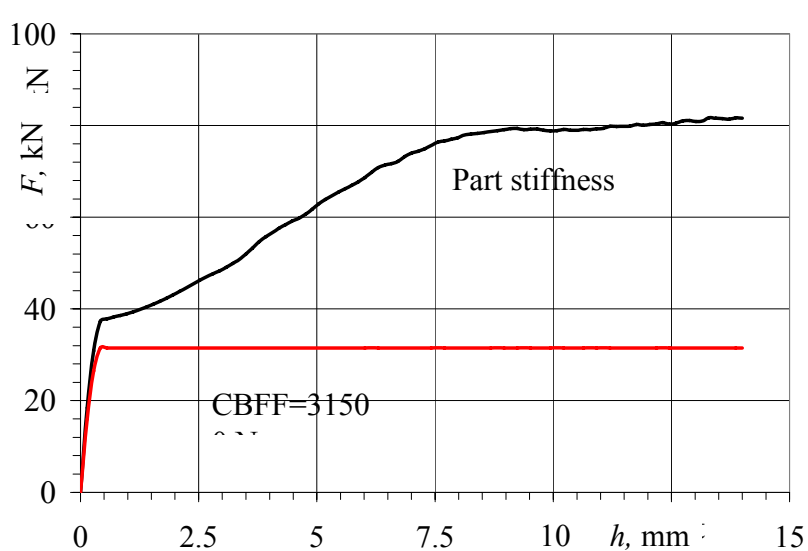

Fig. 7 Stiffness curve of a formed part from material AISI 304 (formed with CBHF)

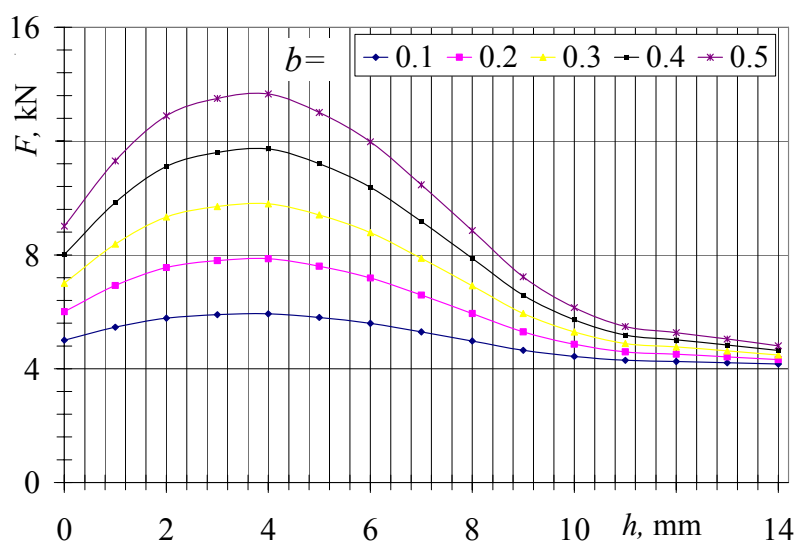

Fig. 8 Coefficient $\mathrm{b}$ in relation to punch displacement when $q-5000$

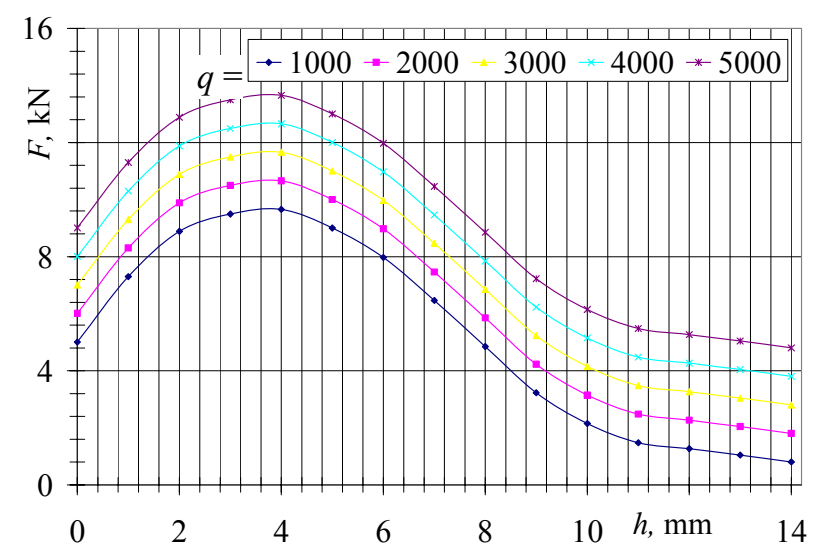

Fig. 9 Coefficient $q$ in relation to punch displacement when $b-0.5$

0 to $10 \mathrm{~mm}$ ). Then the part is being stretched over the punch surface (from 10 to $14 \mathrm{~mm}$ ) the coefficient $\mathrm{b}$ do not really have any influence on material deformation properties. In Fig. 9 below can be seen the relation of coefficient $q$ on punch displacement for material AW 6082-T6. The value was changed from 1000 to 5000 in order to investigate how the curve changes its shape. The result reveals that the change of coefficient value has linear correlation to variable blank holding force. If we change coefficient $q$ by the value of 1000 the whole curve changes its position by the same amount on ordinate (VBHF) axis. In Fig. 10 two forming limit diagrams for material AISI 304 can be seen. Fig. 10, a is for metal sheet formed with constant holding 
force and Fig. 10, $\mathrm{b}$ is for metal sheet formed with variable holding force. As mentioned, FLD consist of two axis of deformation: on the axis of deferred minor strain is given and on the axis of ordinate is deferred major strain is given. The ratio of these strains is formulated as coefficient $\beta[1,5,7,16]$.

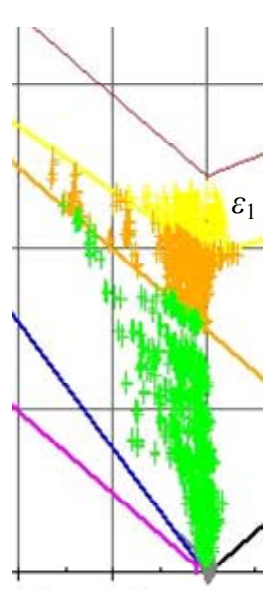

$-0.2-0.1 \quad 00.1 \varepsilon_{2}$

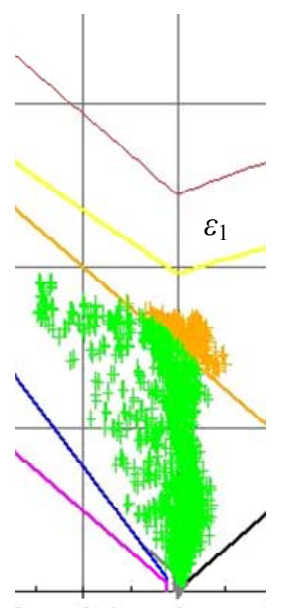

$-0.1 \quad 0 \quad 0.1$

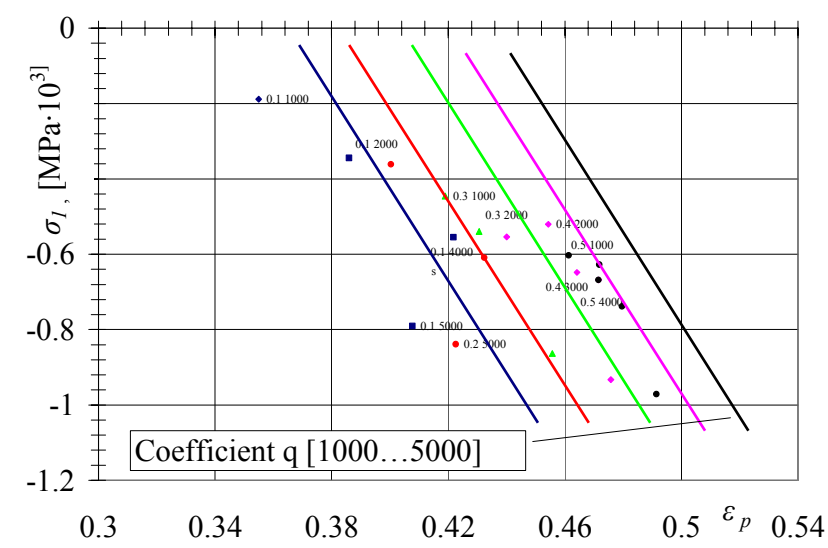

Fig. 12 Significance of coefficients $q$ in respect to $b$ for material AW6082-T6

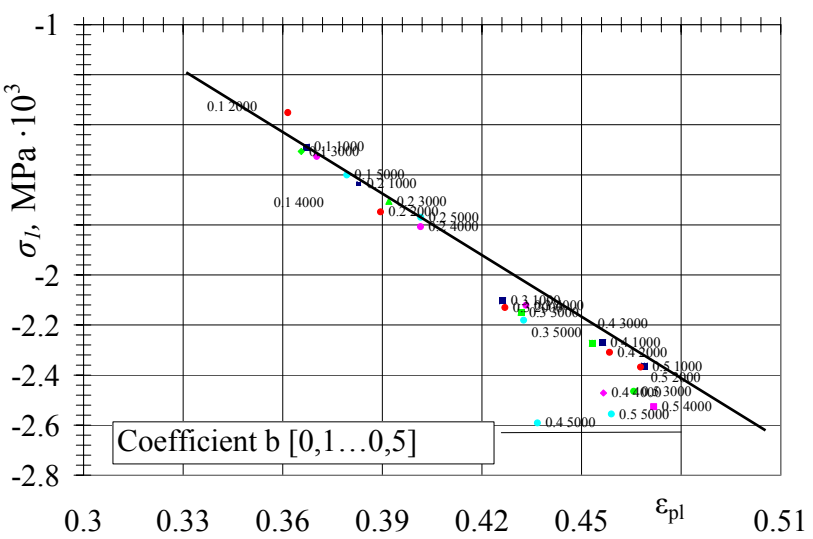

Fig. 13 Significance of coefficients $q$ in respect to $b$ for material L63

to correct or to control certain value of Variable blank holding force, in order to minimize principal stress $\sigma_{1}$ and

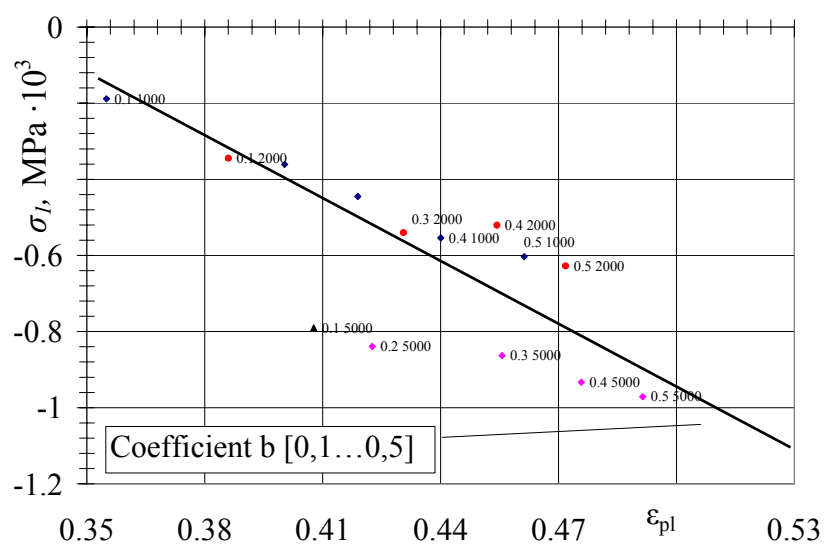

Fig. 111 Significance of coefficients $q$ in respect to $b$ for material AW6082-T6

plastic strain $\varepsilon_{p l}$. In the figures below empirical experimental analysis for investigated materials: AW 6082-T6, L63, and AISI 304 is provided. Fig. 11Fig. 16 represent the significance of coefficients $q$ and $b$ for the investigated materials. In the Fig. 11,Fig. 13 and Fig. 15 we have changed coefficient $b$ in respect to $q$, when $q$ is in constant. Similarly in the Fig. 12,Fig. 14 andFig. 16 we changed coefficient $q$ in respect to $b$, when $b$ is in constant. On the first attempt the results revealed that increasing value of $b$ and leaving the same $q$ gives linear relation of stress-strain state, so we resume that increasing coefficient $b$ from 0.1 to 0.5 increases stress strain state value from $\left[\varepsilon_{p l}=0.355, \sigma_{1}=188.4\right]$ to $\left[\varepsilon_{p l}=0.462, \sigma_{1}=603\right]$ if

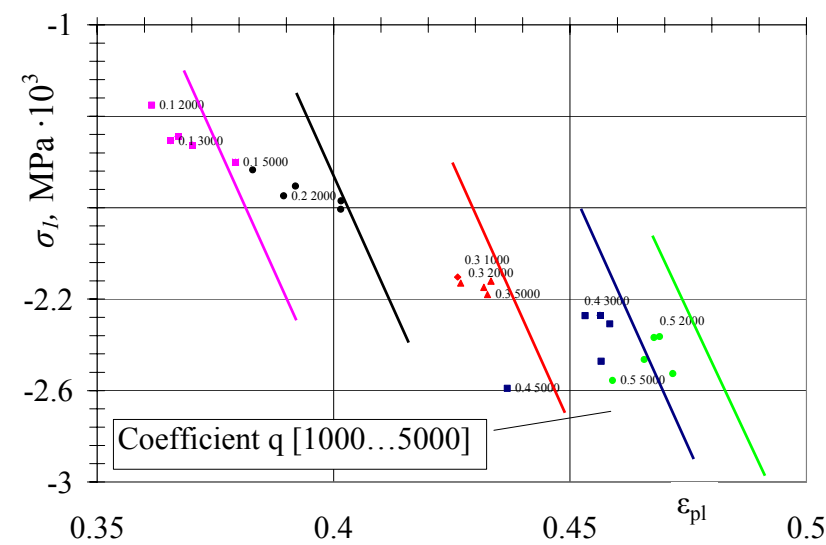

Fig. 14 Significance of coefficients $q$ in respect to $b$ for material L63



Fig. 15 Significance of coefficients $q$ in respect to $b$ for material AISI 304 


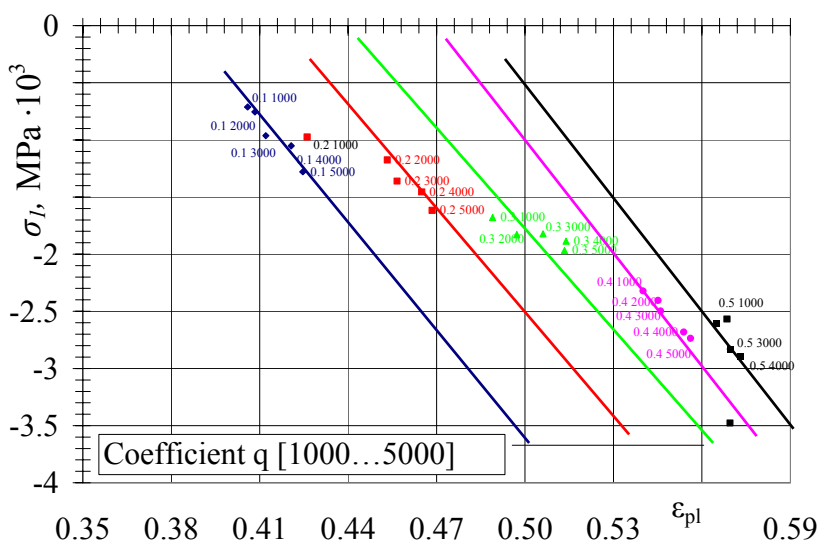

Fig. 16 Significance of coefficients $q$ in respect to $b$ for material AISI 304

$[q=1000]$ for material AW6082-T6. If increasing value $q$ and leaving coefficient $b$ constant we are get several states of stress-strain values.

\section{Conclusions}

In the paper we introduced variable blank holding force which can be significantly decreased final values of strains, there fore following conclusion can be derived:

1. An equation describing variable blank holding force $F_{V B H F}$ has been proposed.

2. It's been determined, that the change of the angle $\alpha$ relative to unchanged position of the matrix vary by the linear function before the 10th step of the punch displacement $h$.

3. After the 10th step of the punch displacement $h$ the change of the angle $\alpha$ changes its linear dependence to nonlinear.

4. Angle $\alpha$ nonlinearity has straight forward influence to proposed variable blank holding force function.

5. Initial coefficients $q$ and $b$ values for investigated materials were proposed.

6. Coefficient $b$ has an influence on the material deformation properties only while the part is being bend. It does not have any influence on the material deformation properties while the part is being stretched.

7. The change of coefficient $q$ value has linear correlation to variable blank holding force.

8. Increasing coefficient $b$ from 0.1 to 0.5 , when $q$ is 1000 , increases stress strain state value from $\left[\varepsilon_{p l}=0.355, \sigma_{1}=188.4\right]$ to $\left[\varepsilon_{p l}=0.462, \sigma_{1}=603\right]$ for material AW6082-T6, $\left[\varepsilon_{p l}=0.367, \sigma_{1}=1488.4\right]$ to $\left[\varepsilon_{p l}=0.469, \sigma_{1}=2364\right]$ for material L63, $\left[\varepsilon_{p l}=0.4, \sigma_{1}=712\right]$ to $\left[\varepsilon_{p l}=0.565, \sigma_{1}=2609\right]$ for material AISI 304.

9. Increasing coefficient $q$ from 1000 to 5000, when $b$ is 0.1 , increases stress strain state value from $\left[\varepsilon_{p l}=0.355, \sigma_{1}=188.4\right] \quad$ to $\left[\varepsilon_{p l}=0.402, \sigma_{1}=790\right]$ for material AW6082-T6, $\left[\varepsilon_{p l}=0.367, \sigma_{1}=1488.9\right]$ to $\left[\varepsilon_{p l}=0.379, \sigma_{1}=1600\right] \quad$ for material L63, $\left[\varepsilon_{p l}=0.4, \sigma_{1}=712\right] \quad$ to $\quad\left[\varepsilon_{p l}=0.42, \sigma_{1}=1279\right]$ for material AISI 304.

10. Values of coefficients $b$ and $q$ give a basic knowledge of how the strain can be controlled.

\section{References}

1. Aleksandrovic, S.M.; Stefanovic, M. 2005. Significance of strain path in conditions of variable blank holding force in deep drawing, Journal for Technology of Plasticity 30(1-2): 25-36.

2. Aleksandrovic, S.M.; Stefanovic, M.; Vujinovich, T. 2005. Significance and limitations of variable blank holding force application in deep drawing process, Tribology in Industry, vol. 27, No. 1\&2: 48-54.

3. Yoon, H.; Aleksandrov, S.; Chung, K.; Dick, R.E.; Kang, T.J. 2006. Prediction of critical criterion to prevent wrinkles in axis symmetric cup drawing, Material Science Forum, vols. 505-507: 1273-1278.

4. Kumpikas, L. 1957. Metalworking by Pressure. Public political and Science Literature Publishing. 507p. (in Lithuanian).

5. Bortkevičius, R.; Dundulis, R.; Karpavičius, R. 2010. Investigation of dependences of stress strain state properties from forming metal sheet holding force, Mechanika 5(85): 19-24.

6. Metal Forming Handbook. 1998. Schuler. Berlin, Springer. 573p

7. Bortkevičius, R.; Dundulis, R. 2009. FLD diagram evenness and dependence from the type of holders holding load. 14th International Conference "Mechanika-2009": proceedings of 14th international conference, April 2-3, 2009, Kaunas, Lithuania, 57-62.

8. Aleksandrovic, S.; Stefanovic, M.; Vujinovich, T. 2003. Variable tribological conditions on the blank holder as significant factor in deep drawing process. 8th International Tribology Conference, Beograd, 8-10: 368-372.

9. Mosallam, A.; Wifi, A. 2007. Some aspects of blankholder force schemes in deep drawing process. Cairo University, Giza 12316, Egypt, volume 24: 315-323.

10. Junevičius R.; Bogdevičius, M. 2010. Mathematical modelling of network traffic flow, Transpor 24(4): 333338.

11. Kheirkhah A. S.; Esmailzadeh A.; Ghazinoory S. 2010. Developing strategies to reduce the risk of hazardous materials transportation in Iran using the method of fuzzy swot analysis, Transport 24(4): 325-332.

12. Bortkevičius, R.; Dundulis, R. 2010. Metal sheet stiffness modulation in formed metal sheet part. 15 th International Conference "Mechanika-2010": proceedings of 15th international conference, April 8-9, 2010, Kaunas, Lithuania, 86-91.

13. Marciniak, Z. 2002. Mechanics of Sheet Metal Forming. Oxford, 228p.

14. Jensen B. C.; Lapko A. 2010. On shear reinforcement design of structural concrete beams on the basis of theory of plasticity, Journal of Civil Engineering and Management 15(4): 395-403.

15. Kalpakjian, Schmid. 2001. Manufacturing Engineering and Technology, Prentice-Hall, 1280p.

16. Gbelingardi, A.C.; Fariello M. 1993. Considerations on the interaction between the press structure and the 
tool in the deep drawing simulation, Journal de Physique IV Colloque C7, supplement au Journal de Physique 111, volume 3, november 1993: 1181-1186.

\section{R. Bortkevičius, R. Dundulis, R. Karpavičius}

\section{KINTAMOS METALO LAKŠTO PRISPAUDIMO JËGOS CHARAKTERIZAVIMAS IR VYSTYMAS}

\section{R e z i u m è}

Šis darbas yra autorių ankstesnių darbų tęsinys. Jame nagrinejjama kintamos metalo lakšto prispaudimo jègos įtaka pagrindinèms detalès formavimo savybėms. Čia pateikiama nauja analitinė išraiška, kuri charakterizuoja kintamą prispaudimo jègą. I šią išraišką ittrauktos visos pagrindinès detalès formavimo savybes įtakojančios sudètinès dalys, tokios kaip: deformacijos greitis, faktinis medžiagos itempių būvis, statinis ir dinaminis trinties koeficientai, tam tikras detalès storis kaip funkcija nuo puansono poslinkio, bei du labai svarbūs empiriniai koeficientai. Pastarieji charakterizuoja ir itakoja kintamos prispaudimo jègos formą ir dydi. Palyginus deformacijų būvius po pilno detalès išformavimo, esant pastoviai ir kintamai prispaudimo jègai, iš ribinio formavimo diagramos (FLD) matome, kad kintama prispaudimo jèga ženkliai sumažina galinę plastinių deformacijų būvio vertę.

\section{R. Bortkevičius, R. Dundulis, R. Karpavičius}

\section{CHARACTERIZATION AND DEVELOPMENT OF METAL SHEET VARIABLE BLANK HOLDING FORCE}

\section{S u m m a r y}

The present paper is a continuation of the authors' works. The paper examines a variable blank holding force of sheet metal on overall forming details. We present a new analytical expression which characterizes a variable holding force. This expression covers all the main components affecting forming components, such as: strain rate, the actual material stress state, static and dynamic friction coefficients, the specific details of the thickness as a function of punch displacement, and two very important empirical factors. These empirical coefficients directly charactere variable blank holding force by changing its shape and size. Comparison of constant and variable blank holding force strain rate state after the full forming operation of an investigated metal sheet part is presented in the forming limit diagram (FLD) diagram, where clearly can be seen that a variable blank holding force significantly reduces final plastic strain value.

\section{Р. Борткявичиус, Р. Дундулис, Р. Карпавичюс}

\section{ХАРАКТЕРИСТИКА И РАЗВИТИЕ ПЕРЕМЕННОЙ ПРИЖИМАЮЩЕЙ СИЛЫ ЛИСТОВОГО МЕТАЛЛА}

Р е 3 ю м е

Работа является продолжением предыдущих работ авторов. В ней рассматривается влияние переменной прижимающей силы листового металла на главные свойства формирования детали. Представлено новое аналитическое выражение, которое характеризует переменную прижимающую силу. Это выражение охватывает все основные компоненты, влияющие на свойства формирования детали, такие как: скорость деформации, фактическое состояние напряжения материала, статический и динамический коэффициенты трения, определена толщина детали в зависимости от перемещения пуансона, и два очень важных эмпирических коэффициентов. Последние коэффициенты характеризуют и влияют на форму и величину переменной прижимающей силы. После сопоставления деформированного состояния после полной деформации материала, при постоянной и переменной силе зажима, на предельной диаграмме формирования (FLD) можно заметить, что переменная прижимающая сила значительно уменьшает окончательное значение пластической деформации.

Received December 14, 2010

Accepted May 27, 2011 